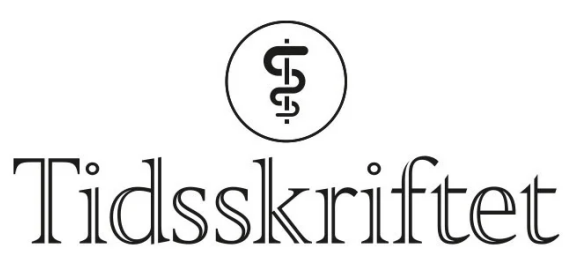

DEN NORSKE LEGEFORENING

\title{
Engasjerende om synssansen og øyesykdommer
}

ANMELDELSER

OLAV H. HAUGEN

Haukeland universitetssykehus Øyeavdelingen

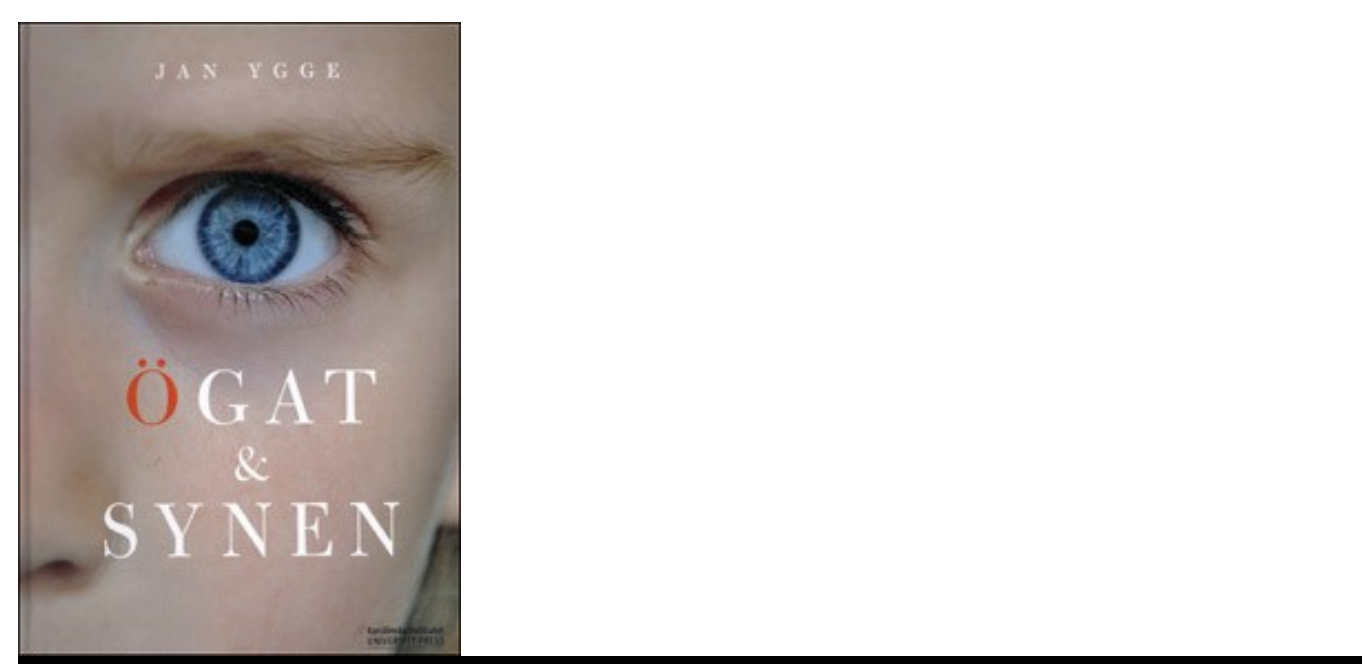

Ygge, Jan

Ögat och synen

285 s, ill. Stockholm: Karolinska Institutet University Press, 2011. Pris SEK 298

ISBN 978-91-85565-21-4

Jan Ygge (f. 1953), overlege ved S:t Eriks Ögonsjukhus og professor ved Institut för neurovetenskap ved Karolinska Institutet, har skrevet bok om øynene, synssansen og øyesykdommer. Man leter forgjeves i innledningen etter hvem som er målgruppen. Men når man begynner å lese, skjønner man raskt at den først og fremst er skrevet for den «interesserte allmennhet». Ygge har bestrebet seg på å skrive på vanlig svensk om til dels svært vanskelige temaer: øyets oppbygning, hjernens bearbeiding av synsinntrykk, øyet som optisk system, for ikke å forglemme de ulike sykdommer som kan ramme øynene og synssansen. Etter min mening har han lyktes svært godt - man merker umiddelbart 
forskerens medrivende entusiasme og engasjement, samtidig som han demonstrerer en utrolig evne til å forklare kompliserte ting på en lett forståelig måte. Jeg får noe av samme opplevelsen som da jeg leste Bill Brysons A short history of nearly everything (2003), men Ygge går atskillig grundigere inn i mange temaer. Eksempelvis er kapitlet om samspillet mellom øynene og hjernen på 52 sider og det om øyets optikk på hele 42 sider!

Det er to hoveddeler. Den første omhandler øynenes anatomi og synets normalfysiologi, den andre øyesykdommer. Den siste er i sin tur inndelt etter når i livet de ulike sykdommene typisk opptrer. I tillegg er det et morsomt kapittel om synssansen hos ulike dyr. Ögat och synen har stive permer, godt papir, noen utsøkte illustrasjoner og bilder og en meget tiltalende layout.

I dagens helsetjeneste legges det stor vekt på saklig og god pasientinformasjon. Ygges bok er etter min mening et eksempel på glimrende medisinsk informasjon på et høyt faglig plan som samtidig er tilgjengelig for legfolk.

Det er noen få faktafeil som trekker litt ned. For eksempel er definisjonen av dioptri i faktaboksen på side 81 blandet med definisjonen av prismedioptri. Dessuten skriver forfatteren på side 137 at når man er under vann, blir man svært nærsynt. Det er imidlertid det omvendte som er tilfellet, man blir kraftig langsynt under vann, da man ikke lenger har det store spranget i brytningsindeks mellom luft og hornhinne.

Etter min mening er ikke den delen som omhandler øyesykdommer, systematisk og komplett nok til at dette kan fungere som fullverdig lærebok for medisinstudenter. Men jeg vil tro at mange medisinstudenter og andre øyeinteresserte i Sverige vil kjøpe den og lese den nettopp fordi den er så lettlest og velskrevet, ikke minst i behandlingen av deler av øyefaget som man finner mindre om i vanlige lærebøker. Så til kolleger som synes det er lett å lese svensk: Kjøp den og kos deg!

Publisert: 20. september 2011. Tidsskr Nor Legeforen. DOI: 10.4045/tidsskr.11.0675

(C) Tidsskrift for Den norske legeforening 2023. Lastet ned fra tidsskriftet.no 26. april 2023. 